\title{
ROLE OF CHEMISTRY IN THE IMPLEMENTATION OF SUSTAINABLE DEVELOPMENT GOALS
}

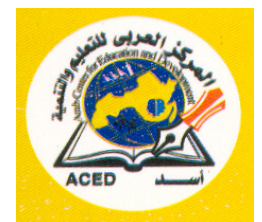

Prof. Lobna Abdel-Mohsen Ebaid Nassr*

\section{INTRODUCTION}

What is the sustainable development? It's a very important question to be addressed in our minds. The most noticeable definition of SD was presented by the "World Commission on the Environment and Development" in $1987^{[1]}$. It says that "SD is a development that meets the needs of the present without compromising the ability of future generations to meet their own needs." It implies that SD is a composite concept. The needs of future generations, and the abilities required to meet them, are not clear nowadays. Another issue is that the needs of each generation are very heterogeneous and dependent on numerous factors. This difficulty is a clear problem to companies and individuals in their efforts in being sustainable ${ }^{[2]}$.

Prof. of Physical Chemistry, Director of Quality Management Unit, Faculty of Science - Sohag University 
Sustainability is usually defined in terms of interconnected social, ecological, and economical concerns ${ }^{[3]}$.

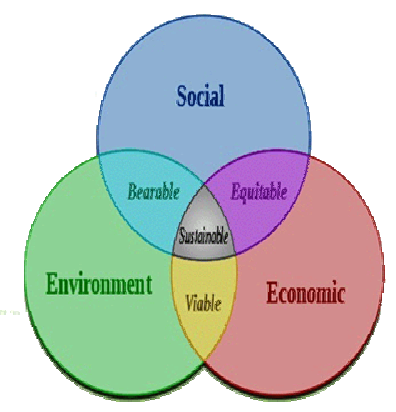

\section{SUSTAINABLE DEVELOPMENT GOALS (SDGS)}

The United Nations in September 2015 agreed on a new global agenda to take the world on a sustainable pathway. The 2030 agenda for sustainable development, provides a shared plan for peace and wealth for people and our planet nowadays and into the future. The 17 sustainable development goals (SDGs) are a crucial call for action by both developed and developing countries. It was designed that ending poverty and other deficiencies must achieved parallel with develop both health and education, reduce inequality, encourage economic growth and preserve our oceans and forests. SDGs are started to be implemented from January 2016 in all around the world. 
The 17 SDGs build on decades of work by countries and the UN: the Earth Summit in Rio de Janeiro, Brazil (1992) - Millennium Summit (2000) - World Summit on Sustainable Development in South Africa (2002) - United Nations Conference on Sustainable Development (Rio+20) in Rio de Janeiro, Brazil (2012) - General Assembly of UN (2013) - General Assembly of UN (2015).

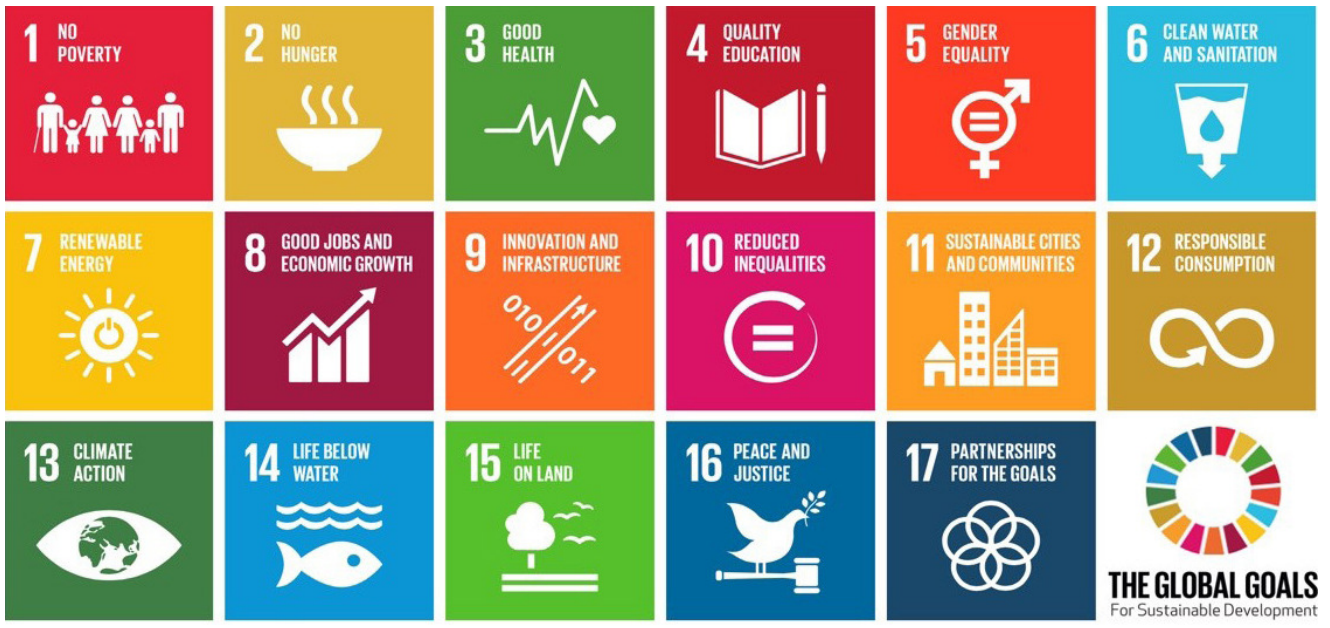

\section{GOAL 1: NO POVERTY[4]}

One of the greatest challenges facing humanity is eliminating poverty in all its forms. Too many people are still struggling for the most basic human needs, while the number of people living in extreme poverty 1 Noverty dropped by more than half between 1990 and 2015,. 


\section{Facts and Figures:}

$\checkmark 736$ million people still live in extreme poverty.

$\checkmark 10 \%$ of the world's population lives in extreme poverty, down from $36 \%$ in 1990.

$\checkmark$ Some 1.3 billion people live in multidimensional poverty.

$\checkmark$ Half of all people living in poverty are under 18 years.

$\checkmark$ One person in every ten is extremely poor.

\section{GOAL 2: NO HUNGER[4]}

Rapid economic growth and increased agricultural productivity over the past two decades dropped the number of undernourished people by almost half. Many developing countries that used to suffer from famine and hunger can nowadays meet

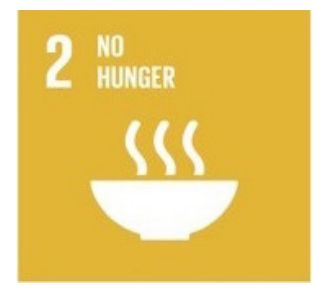
the nutritional needs of the most vulnerable.

\section{Facts and figures:}

$\checkmark$ 1/9 people is undernourished.

$\checkmark 2 / 3$ of the total hungriest people are in Asia.

$\checkmark \quad 1 / 4$ of children suffer from stunted growth. In some developing countries, it's as high as $1 / 3$. 
$\checkmark$ Agriculture is the world's largest employer, providing livelihoods for $40 \%$ of the population.

$\checkmark$ If women farmers had the same resources as men, the number of hungry people in the world could be reduced by 150 million.

$\checkmark$ Since the 1900 s, some $75 \%$ of crop diversity has been lost from farmers' fields.

\section{GOAL 3: GOOD HEALTH AND WELL-BEING[4]}

Health is a good reflector of sustainable development. Healthy people contribute effectively and efficiently to the development of their countries. The world has made great progress against several of the leading causes of death and

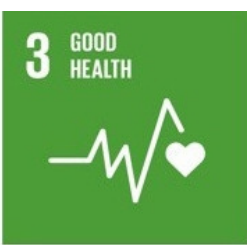
disease.

\section{Facts and Figures:}

$\checkmark$ At least 400 million people have no basic health services, and $40 \%$ of the world's people lack social protection.

$\checkmark$ More than 1.6 billion people live in fragile settings where protracted crises, combined with weak national capacity to deliver basic health services, present a significant challenge to global health. 
$\checkmark$ By the end of 2017, 21.7 million people living with HIV were receiving antiretroviral therapy.

$\checkmark$ Every 2 seconds someone aged 30 to 70 years dies prematurely from non-communicable diseases - cardiovascular disease, chronic respiratory disease, diabetes or cancer.

$\checkmark 7$ million people die every year from exposure to fine particles in polluted air.

\section{GOAL 4: QUALITY EDUCATION[4]}

Since 2000, there has been enormous progress in achieving the target of universal primary education. The total enrolment rate in developing regions reached $91 \%$ in 2015, and the worldwide number of children out of school has dropped by almost half. There has also been a dramatic increase

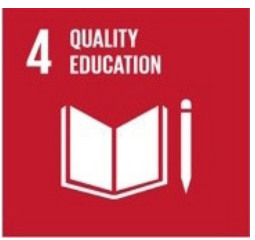
in literacy rates, and many more girls are in school than ever before. These are all remarkable successes.

\section{Facts and Figures:}

$\checkmark 57$ million primary-aged children remain out of school.

$\checkmark$ In developing countries, 1/4 girls is not in school. 
$\checkmark$ About half of all out-of-school children of primary school age live in conflict-affected areas.

$\checkmark 103$ million youth worldwide lack basic literacy skills, and more than $60 \%$ of them are women.

$\checkmark$ Globally, 6 out of 10 children and adolescents are not achieving a minimum level of proficiency in reading and math.

\section{GOAL 5: GENDER EQUALITY ${ }^{[4]}$}

Ending all forms of discrimination against women and girls is not only a basic human right, but is also crucial to accelerating sustainable development. It was found that empowering women and girls has a multiplier effect, and helps

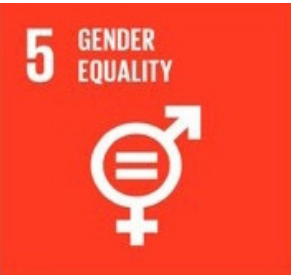
drive economic growth and development.

\section{Facts and Figures:}

$\checkmark$ Women earn only 77\% from that men get for the same work.

$\checkmark$ Women represent just $13 \%$ of agricultural landholders.

$\checkmark$ Almost 750 million women and girls alive today were married under the age of 18 .

$\checkmark 2 / 3$ of developing countries have achieved gender equality in primary education. 
$\checkmark$ Only $24 \%$ of national parliamentarians were women as of November 2018 (it was $11.3 \%$ in 1995).

\section{GOAL 6: CLEAN WATER AND SANITATION[4]}

Water scarcity affects more than $40 \%$ of people around the world. This ratio is expected to increase with the rise of global temperatures because of climate change. Although 2.1 billion people have gained access to improved water sanitation since 1990, decreasing supplies of safe drinking water is a major problem impacting every continent.

\section{Facts and Figures:}

$\checkmark$ Each day, nearly 1,000 children die due to preventable water and sanitation-related diseases.

$\checkmark 2.4$ billion people worldwide do not have access to basic sanitation services like toilets or latrines.

$\checkmark 80 \%$ of wastewater from human activities is discharged into waterways without any pollution removal. 


\section{GOAL 7: AFFORDABLE AND CLEAN ENERGY[4]}

Between 2000 and 2016, the number of people with electricity increased from 78 to $87 \%$, and the number of people without electricity dipped to just below one billion.

\section{Facts and figures:}

$\checkmark \quad$ 1/7 people still lacks electricity, and most of them live in rural areas of the developing world.

$\checkmark$ Energy is the main contributor to climate change; it produces around $60 \%$ of greenhouse gases.

$\checkmark$ Building and industry electricity consumption can be reduced by $14 \%$.on applying more efficient energy standards.

$\checkmark$ More than $40 \%$ of the world's population used polluting and unhealthy fuels for cooking.

$\checkmark$ From 2015, more than $20 \%$ of power was generated through renewable sources.

$\checkmark$ The renewable energy sector employed a record 10.3 million people in 2017. 


\section{GOAL 8: DECENT WORK AND ECONOMIC GROWTH}

In developing countries, the middle class now makes up more than $34 \%$ of total employment; this number has almost tripled from 1991 to 2015.

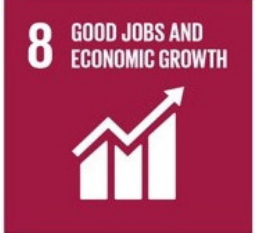

\section{Facts and Figures:}

$\checkmark$ The global unemployment rate stood at 5.6\% in 2017 .

$\checkmark$ Unemployment among youth (aged 15 to 24 ) reached $13 \%$ in 2014, nearly three times higher than the rate for adults.

$\checkmark$ In 2017 there were around 300 million workers in extreme poverty, living on less than US\$1.90 per day.

$\checkmark 470$ million jobs will be needed to absorb new entrants to the labor market between 2016 and 2030 .

$\checkmark$ Only $29 \%$ of the global population has inclusive social security; the other $71 \%$ are not or partially protected.

\section{GOAL 9: INDUSTRY, INNOVATION AND INFRASTRUCTURE[4]}

Investment in infrastructure and innovation are critical motives of economic growth and development. Mass transport and renewable energy are becoming very important, due to the growth of new industries and information and

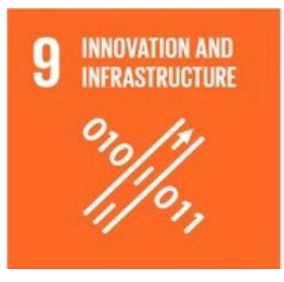
communication technologies. 


\section{Facts and Figures:}

$\checkmark 2.4$ billion people lack access to basic sanitation, and almost 800 million people lack access to clean water.

$\checkmark 2.6$ billion people in developing countries do not have access to constant electricity.

$\checkmark$ More than 4 billion people still do not have access to the Internet; $90 \%$ of them are in the developing world.

$\checkmark$ The renewable energy sectors currently employ more than 2.3 million people; the number could reach 20 million by 2030 .

$\checkmark$ In developing countries, only just $30 \%$ of agricultural products undergo industrial processing, compared to $98 \%$ high-income countries.

\section{GOAL 10: REDUCED INEQUALITIES[4]}

The richest $10 \%$ people earning up to $40 \%$ of total global income. While The poorest $10 \%$ earn only between $2 \%$ and $7 \%$ of total global income. In developing countries, inequality has increased by $11 \%$ according to the growth of

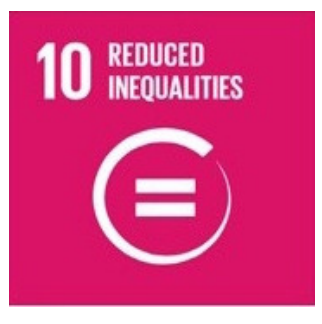
population. 


\section{Facts and Figures:}

$\checkmark$ It will take 217 years to close the gender gap in employment opportunities and pay (according to The World Economic Forum).

$\checkmark$ In developing countries, rural women are up to 3 times more likely to die in childbirth than women living in urban centers.

\section{GOAL 11: SUSTAINABLE CITIES AND COMMUNITIES[4]}

Nowadays, more than half of the world's population live in urban areas. By 2050, that ratio will rise to $2 / 3$ of all humanity. Sustainable development cannot be achieved without significantly transforming the way we build and

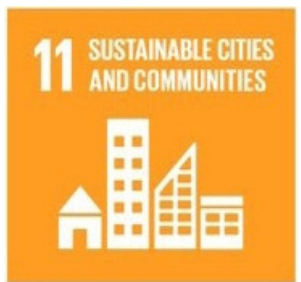
manage our urban spaces.

\section{Facts and Figures:}

$\checkmark$ Cities occupy just 3\% of the Earth's land but account for 60 to $80 \%$ of energy consumption and $75 \%$ of carbon emissions.

$\checkmark$ There are 828 million people live in slums, and the number is rising.

$\checkmark$ By 2014, the number of "mega-cities" had reached 28 . 
$\checkmark$ In the coming decades, $95 \%$ of urban expansion will take place in the developing world.

$\checkmark 1.2$ billion jobs depend on a healthy and stable environment.

\section{GOAL 12: RESPONSIBLE CONSUMPTION AND PRODUCTION[4]}

Achieving economic growth and sustainable development requires instant reduction of ecological footprint by changing the way of

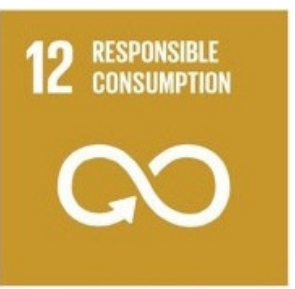
producing and consuming goods and resources. Agriculture is the biggest user of water worldwide, and irrigation now claims close to $70 \%$ of all freshwater for human use.

\section{Facts and Figures:}

$\checkmark 1.3$ billion tons of food is wasted every year, while almost 2 billion people go hungry or undernourished.

$\checkmark$ The food sector accounts for around $22 \% \%$ of total greenhouse gas emissions, largely from the conversion of forests into farmland.

$\checkmark$ Globally, 2 billion people are overweight or obese.

$\checkmark$ Only $3 \%$ of the world's water is fresh (drinkable), and humans are using it faster than nature can replace it. 
$\checkmark$ If people everywhere switched to energy efficient light-bulbs, the world would save US\$120 billion annually.

$\checkmark 1 / 5$ of the world's final energy consumption in 2013 was from renewable sources.

\section{GOAL 13: CLIMATE ACTION[4]}

Climate change affects every country in the world. Greenhouse gas emissions continue to rise every year. Additional, global warming is causing long-lasting changes to the climate system, which threatens irreversible

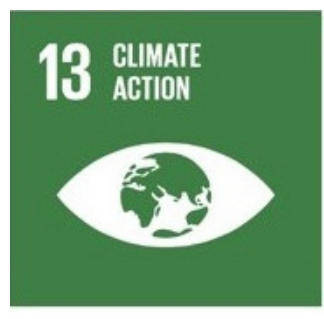
consequences if no action is taken.

\section{Facts and Figures:}

$\checkmark$ Global sea levels have risen by about $20 \mathrm{~cm}$ since 1880 and are predictable to rise another $30-122 \mathrm{~cm}$ by 2100 .

$\checkmark$ Global net $\mathrm{CO}_{2}$ emissions must drop by $45 \%$ between 2010 and 2030, and reach net zero around 2050.

$\checkmark$ The energy sector alone will create around 18 million more jobs by 2030, focused specifically on sustainable energy. 


\section{GOAL 14: LIFE BELOW WATER[4]}

The world's oceans drive global systems that make the Earth livable for humankind. Management this vital resource is essential for humanity and to counter balance the effects of climate change.

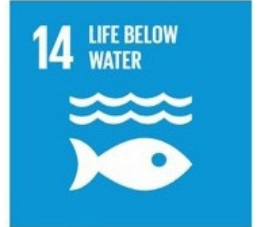

\section{Facts and figures:}

$\checkmark$ The ocean covers 3/4 of the Earth's surface and represents 99\% of the living space on the planet by volume.

$\checkmark$ The ocean contains nearly 200,000 identified species and millions are unknowns.

$\checkmark 40 \%$ of the ocean is affected deeply by pollution, depleted fisheries, loss of coastal habitats and other human activities.

$\checkmark$ The ocean absorbs about 30\% of $\mathrm{CO}_{2}$ produced by humans, buffering the impacts of global warming.

$\checkmark$ More than 3 billion people depend on marine and coastal biodiversity for their livelihoods.

\section{GOAL 15: LIFE ON LAND[4]}

Plant life provides $80 \%$ of our human food. Moreover, agriculture is an important economic resource and means of development. Forests

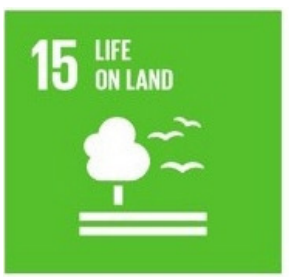


covers about $30 \%$ of the earth's surface, providing vital habitats for millions of species and important sources for clean air and water; as well as being crucial for opposing climate change.

\section{Facts and Figures:}

$\checkmark$ Around 1.6 billion people depend on forests for their livelihoods.

$\checkmark$ Forests are home to more than $80 \%$ of all native species of animals, plants and insects.

$\checkmark 2.6$ billion people depend directly on agriculture for their livelihoods.

$\checkmark$ Nature-based climate solutions can contribution about 1/3 of the $\mathrm{CO}_{2}$ reductions needed by 2030 .

$\checkmark$ Mountain regions provide $60-80 \%$ of the earth's fresh water.

\section{GOAL 16: PEACE, JUSTICE AND STRONG INSTITUTIONS[4]}

Without peace, stability, human rights, and effective governance based on the rule of law no sustainable development. Some regions of the world enjoy sustained peace, security and

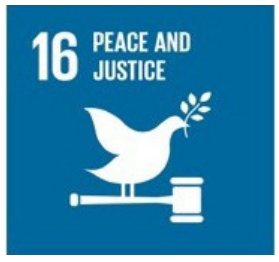
prosperity, while others fall into seemingly endless 
cycles of conflict and violence. This is by no means

unavoidable and must be addressed.

\section{Facts and Figures:}

$\checkmark$ By the end of 2017, 68.5 million people had been forcibly displaced by persecution, conflict, violence or human rights violations

$\checkmark$ There are at least 10 million stateless people who have been denied nationality and its related rights.

$\checkmark 49$ countries lack laws protecting women from domestic violence.

$\checkmark$ In 46 countries, women now hold more than $30 \%$ of seats in at least one chamber of national government.

$\checkmark \quad 1$ billion people cannot prove who they are, and are legally 'invisible'. This includes an estimated 625 million children who were not registered at birth.

\section{GOAL 17: PARTNERSHIPS FOR THE GOALS[4]}

The SDGs can only be realized with a strong commitment to global partnership and cooperation. While official development assistance from developed countries increased by $66 \%$ between

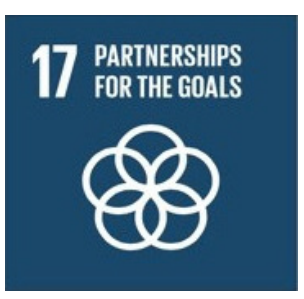

Volume 26 
2000 and 2014, humanitarian crises brought on by conflict or natural disasters continue to demand more financial resources and aid.

\section{Facts and Figures:}

$\checkmark$ The UN Conference on Trade and Development says achieving SDGs will require US\$ 5 trillion to $\$ 7$ trillion in annual investment.

$\checkmark$ Total official development assistance reached a peak of US\$142.6 billion in 2016.

$\checkmark$ In 2016,75\% of international remittances went to developing countries.

$\checkmark$ In 2016, 6 countries met the international target to keep official development assistance at or above $0.7 \%$ of gross national income.

$\checkmark 79 \%$ of imports from developing countries enter developed countries duty-free.

$\checkmark$ More than 4 billion people do not use the Internet, and $90 \%$ of them are from the developing world. 


\section{Chemistry and Sustainable Development (Sustainable (hemistry)}

Chemistry and chemical research can participate in achievement many sustainable development goals such as: clean water and sanitation - clean energy - industry and innovation (chemical fields) - climate issues ...etc. Orientation of chemistry practices and

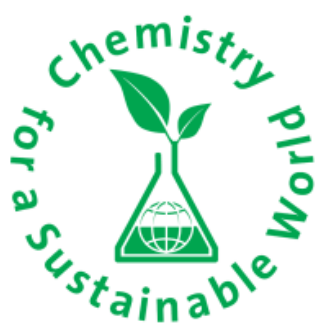
researches toward more sustainable trends is a core of enhancement human life.

Sustainable chemistry ${ }^{[5]}$ is a complete approach where the entire life cycle of chemical products and the related system of actors, institutions and culture is considered. This implicates that all stakeholders along the life cycle chain of chemicals have responsible roles. Besides health and environment, social conditions, research, science and economic aspects have to be considered and balanced within the capacity-limits of our planet. Therefore, sustainable chemistry is considered as the umbrella of green chemistry and safe use of chemicals operations.

\section{Principles of Sustainable Chemistry:}

Design and use of "kind" chemicals. 
$\checkmark$ Development and use of alternative solutions for problematic applications.

$\checkmark$ Reduction of side effects.

$\checkmark$ Conservation of natural resources.

$\checkmark$ Promotion of reuse and recycling.

$\checkmark$ Increase of market opportunities.

$\checkmark$ Application of corporate social responsibility.

Good inspection of SDGs will clearly show the connection between them and chemical aspects. Chemicals are clearly named in: SDG 3 (healthy lives and well-being), SDG 6 (water and sanitation) and SDG 12 (consumption and production). Moreover there are more SDGs also related to sustainable chemistry: SDG 2 (No hunger), SDG 7 (renewable energy), SDG 8 (goof jobs and economic growth), SDG 9 (industry, innovation and infrastructure), SDG 11 (sustainable cities and communities), SDG 13 (climate action), SDG 14 (life below Water), SDG 15 (life on land) and SDG 17 (partnerships for the goals). 


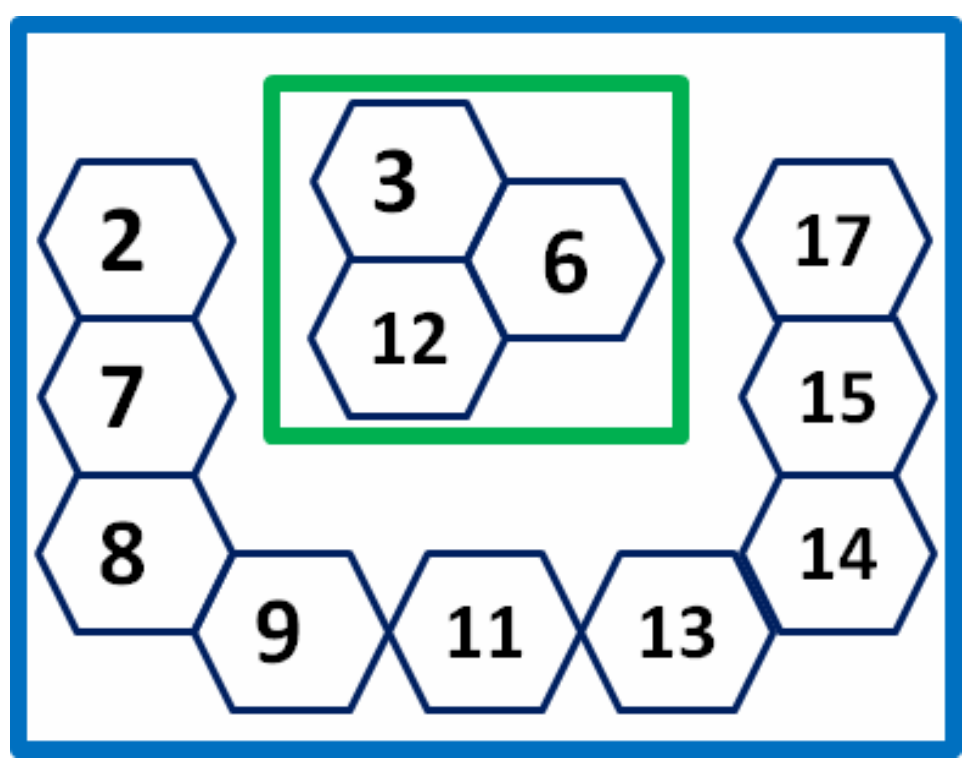

SDGs Connected to Sustainable Chemistry.

\section{Participation of Chemical Researches in SDGs:}

Chemical researches participate in achievement of SDGs as follows:

SDG 2 (No hunger): Increase the agriculture productivity via using the suitable and safe chemical fertilizers.

SDG 3 (Healthy lives and well-being): Pharmaceutical researches are built on changing the chemical composition of drugs to get more effective and safer compositions.

SDG 6 (Water and sanitation): Improve the quality of water (via scientific research) is subjected to many researchers concerning both the chemical and physical properties of 
water $^{[6]}$. Moreover, many researches are focused on removal of water contamination by new cheap methods ${ }^{[7-9]}$

SDG 7 (Renewable energy): New energy resources are manufactured depending on chemical research such as production of hydrogen as energy source ${ }^{[10]}$.

SDG 8 (Good jobs and economic growth): This goal is performed by establishment of clean chemical industries (less wastes and inexpensive raw materials).

SDG 9 (Industry, innovation and infrastructure): Nowadays, many researches are focused on preparation and characterization of new alloys which can be used for technological infrastructure.

SDG 11 (Sustainable cities and communities): Improve air quality and management of chemical wastes are the basic indicators for sustainable communities.

SDG 12 (Consumption and production): Reused and re-cyclization of the materials with chemical origin (paper - glass - metals .... $)^{[11]}$ are crucial factors to reduce the consumption of natural resources.

SDG 13 (Climate action): chemistry participates in reducing the climate changes by applied economical techniques to reduce 
the emission of harmful gases such as preparation of materials can be used as adsorbent for $\mathrm{CO}_{2}$ from the industrial emissions.

SDG 14 (Life below Water) and SDG 15 (Life on land): they can be implemented by prohibition of chemical contamination of both water and land.

SDG 17 (Partnerships for the goals): sustainable development cannot be attained without the international cooperation in all the above listed items especially in the field of chemical aspects.

\section{Green Chemistry:}

Green Chemistry is commonly presented as a set of 12 principles[12]. The principles include instructions for professional chemists to implement new chemical compound, and new synthesis and technological processes.

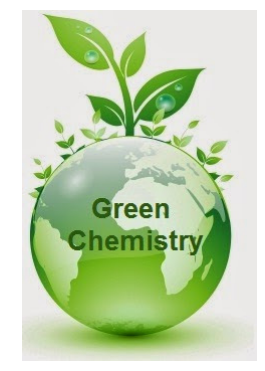

Green chemistry is considered as the synthesis of substance in such a way that is proper, non-polluting and protected and which requires lowest amounts of resources and energy but generating slight or no waste material ${ }^{[13]}$. 


\section{Green Chemistry Principles:}

\section{(1) Prevent of wastes:}

It is better to prevent waste than to treat or clean up waste after it has been created.

\section{(2) Atom Economy:}

Synthetic methods should be designed to maximize incorporation of all materials used in the process into the final product. It if very important to address the following question in our mind: "what atoms of the reactants are incorporated into the final desired product(s) and what atoms are wasted?". Chemists must achieve maximum percent yield and design syntheses that maximize the incorporation of the atoms of the reactants into the desired product.

$\%$ Atom Economy $=(\mathrm{FW}$ of atoms utilized $/ \mathrm{FW}$ of all reactants $) \mathrm{X} 100$

4<smiles>CC(=O)c1ccccc1</smiles>

$+\mathrm{NaBH}_{4}+4 \mathrm{H}_{2} \mathrm{O}$

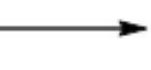

4

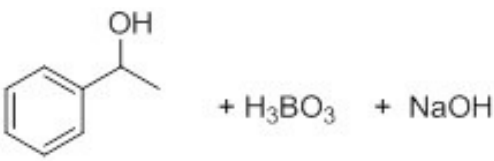

$81 \%$ atom economy<smiles>CCC(=O)c1ccccc1</smiles>

$+\mathrm{H}_{2}$

\section{Pd-on-C catalyst}

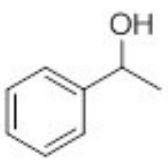

$100 \%$ atom economy 


\section{(3) Cess Hazardous Chemical Syntheses:}

Wherever

practicable, synthetic methods should be designed to use and generate substances that possess little or no toxicity to human health and the environment. If we focus only on the synthetic pathway and ignore all

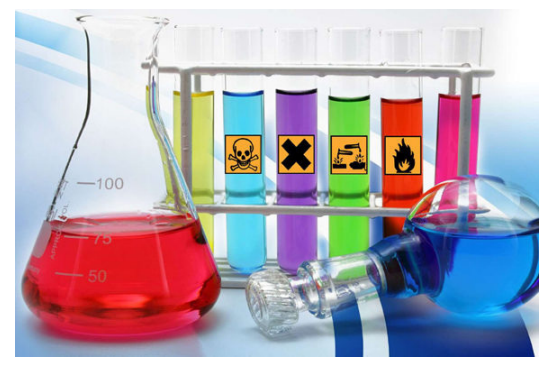
the other "stuff," we will pay a high price.

\section{(4) Designing Safer Chemicals:}

Chemical products should be designed to preserve efficacy of function while reducing toxicity. Achieving this goal requires an understanding of not only chemistry but also of the principles of toxicology and environmental science.

\section{(5) Safer Solvents and Auxiliaries:}

The use of auxiliary substances (solvents, separation agents, etc.) should be made unnecessary whenever possible and, when used, innocuous. 
Solvents classification according to green chemistry principles

\begin{tabular}{|c|c|c|}
\hline Preferred & Useable & Undesirable \\
\hline Water & Cyclohexane & Pentane \\
\hline Acetone & Heptane & Hexane(s) \\
\hline Ethanol & Toluene & Di-isopropyl ether \\
\hline 2-Propanol & Methylcyclohexane & Diethyl ether \\
\hline 1-Propanol & Methyl t-butyl ether & Dichloromethane \\
\hline Ethyl acetate & Isooctane & Dichloroethane \\
\hline Isopropyl acetate & Acetonitrile & Chloroform \\
\hline Methanol & 2-MethylTHF & Dimethyl formamide \\
\hline $\begin{array}{l}\text { Methyl ethyl } \\
\text { ketone }\end{array}$ & Tetrahydrofuran & $\begin{array}{c}\mathrm{N}- \\
\text { Methylpyrrolidinone }\end{array}$ \\
\hline 1-Butanol & Xylenes & Pyridine \\
\hline \multirow[t]{2}{*}{$t$-Butanol } & Dimethyl sulfoxide & Dimethyl acetate \\
\hline & Acetic acid & Dioxane \\
\hline
\end{tabular}


Solvents classification according to green chemistry principles

\begin{tabular}{|l|c|c|}
\hline Preferred & Useable & Undesirable \\
\hline & Ethylene glycol & Dimethoxyethane \\
\hline & & Benzene \\
\hline & Carbon tetrachloride \\
\hline
\end{tabular}

\section{(6) Design for Energy Efficiency:}

Energy requirements should be recognized for their environmental and economic impacts and should be minimized. Synthetic methods should be conducted at ambient temperature and pressure such as:

\section{Ultrasonic Synthesis}

\section{Microwave Synthesis}

Solvothermal Synthesis

\section{(7) Use of Renewable Feedstock:}

A raw material or feedstock should be renewable rather than depleting whenever technically and economically practical. Significant advances have been made in the development of fuels, chemicals and materials from renewable feedstocks. Examples are: 
Biodiesel from plant oils and algae - Bioethanol and butanol from sugars and lignocellulose - Plastics, foams and thermosets from lignin and plant oils - Electronic materials from chicken feathers.

\section{(8) Reduce Derivatives:}

Unnecessary derivatization should be avoided whenever possible. Because such steps require additional reagents and can generate waste. One of the best ways of doing this is the use of enzymes. Enzymes are so specific that they can often react with one site of the molecule and leave the rest of the molecule.

\section{(9) Catalysis:}

Catalytic reagents (as selective as possible) are superior to stoichiometric reagents.

4<smiles>CC(=O)c1ccccc1</smiles>

$+\mathrm{NaBH}_{4}+4 \mathrm{H}_{2} \mathrm{O}$

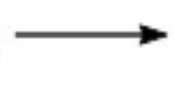

4<smiles>CC(O)c1ccccc1</smiles>
$+\mathrm{H}_{3} \mathrm{BO}_{3}+\mathrm{NaOH}$

$81 \%$ atom economy<smiles>CC(=O)c1ccccc1</smiles><smiles>CC(O)c1ccccc1</smiles>

$100 \%$ atom economy 


\section{(10) Design for Degradation:}

Chemical products should be designed so that at the end of their function they do not persist in the environment and instead break down into innocuous degradation products. It goes with SDG 14 (life below Water), SDG 15 (life on land).

\section{(11) Real-time Analysis for Pollution Prevention:}

Analytical methodologies need to be further developed to allow for real-time in-process monitoring and control prior to the formation of hazardous substances. For examples Analysis can detect: changes in process temperature or $\mathrm{pH}$ prior to a reaction going out of control poisoning of catalysts can be determined and other harmful events can be detected before a major incident occurs.

(12) Inherently Safer Chemistry for Accident Prevention:

Substance and the form of a substance used in a chemical process should be chosen so as to minimize the potential for chemical accidents, including releases, explosions, and fires. 


\section{CONCLUSION:}

Orientation of chemistry and chemical research towards sustainable topics is the main gateway to attain SDGs in the society.

Careful interaction with chemistry and chemical compounds leads to sustainable life. 


\section{REFERENCES}

1. Brundtland, G.H., Our Common Future: The World Commission on Environment and Development. Oxford University Press, Oxford1987.

2. Scott, W.a.G., S., Sustainable Development and Learning - Framing the Issues2003: Routledge Farmer, London.

3. Mulder, K., Sustainable Development for Engineers: A Handbook and Resource Guide2006: Green leaf Publishing, Suffolk, VA.

4. Programme, U.N.D. Sustainable development goals 2019; Available from: https://www.undp.org/content/undp/en/home/s ustainable-development-goals.html.

5. Blum, C., et al., The concept of sustainable chemistry: Key drivers for the transition towards sustainable development. Sustainable Chemistry and Pharmacy 2017. 5: p. 94-104.

6. ASADULLAH, K. NISA, and S.I. KHAN, PHYSICO-CHEMICAL PROPERTIES OF DRINKING WATER AVAILABLE IN EDUCATIONAL INSTITUTES OF KARACHI CITY. Sci., Tech. and Dev., 2013. 32(1): p. 28-33. 
7. Du, W.-N. and S.-T. Chen, Photo-and chemocatalytic oxidation of dyes in water. Journal of Environmental Management, 2018. 206 p. 507-515.

8. Shanker, U., M. Rani, and V. Jassal, Degradation of hazardous organic dyes in water by nanomaterials. Environ Chem Lett, 2017. 15: p. 623-642.

9. HILDEBRAND, H., K. MACKENZIE, and F.-D. KOPINKE, NOVEL NANO-CATALYSTS FOR WASTEWATER TREATMENT. Global NEST Journal, 2008. 10(1): p. 47-53.

10. Commission, E., Progress in Accelerating Clean Energy Innovation 2018.

11. Clark, J.H., From waste to wealth using green chemistry: The way to long term stability. Current Opinion in Green and Sustainable Chemistry, 2017. 8: p. $10-13$.

12. Anastas, P.T. and J.C. Warner, Green Chemistry Theory and Practice 1998: Oxford Univ. Press, New York.

13. Jaiswal, S., et al., APPLICATIONS OF GREEN CHEMISTRY. International Journal on Cybernetics \& Informatics 2017. 6(1/2): p. 127 - 133. 